\title{
HUBUNGAN KARAKTERISTIK PENGEMUDI DENGAN PERILAKU PENGGUNAAN SAFETY BELT
}

\author{
Yuli Astari*Lilis Banowati**
}

\begin{abstract}
ABSTRAK
Dalam perkembangan teknologi mobil sangat berperan penting bagi kehidupan manusia mobil dilengkapi dengan perangkat keamanan yaitu safety belt. Kecelakaan lalu lintas merupakan salah satu penyebab kematian terbesar di Indonesia. Polda Metro Jaya menindak sekitar 235 pengendara yang tidak menggunakan safety belt dan di Bandung pelanggaran mengenai penggunaan safety belt \pm 400 pelanggaran. Data kecelakaan dari Ditjen Perhubungan Darat tahun 2009 total korban kecelakaan pada tahun 2011 mencapai 176.763 orang, dengan rincian 31.185 meninggal dunia, 36.767 luka berat dan 108.811 menderita luka ringan. Menurut studi yang dilakukan oleh Institut Analisis CEESAR, mengatakan jumlah pengemudi truk yang meninggal dan terluka dalam kecelakaan lalu lintas dapat dikurangi 40\% jika mereka semua menggunakan safety belt. UU No 14 tahun 1992 tentang kewajiban menggunakan safety belt, pelanggaran ini dapat dikenakan pidana kurungan 1 bulan atau denda Rp1000.000. Tujuan penelitian ini untuk mengetahui hubungan karakteristik pengemudi dengan perilaku penggunaan safety belt di PT Cipta Hasil Sugiarto Cirebon tahun 2015. Penelitian ini menggunakan instrumen penelitian berupa kuesioner. Rancangan penelitian ini adalah desain cross sectional, dengan populasi seluruh pengemudi di PT Cipta Hasil Sugiarto Cirebon sebanyak 70 responden dan pengambilan sampel menggunakan metode total populasi. Data dianalisis secara statistik menggunakan uji chi square pada tingkat kemaknaan 5\% $(0,05)$.Hasil penelitian ini menunjukkan ada hubungan antara umur dengan perilaku penggunaan safety belt (Pvalue $=0,000)$, tidak ada hubungan antara tingkat pendidikan dengan perilaku penggunan safety belt $($ Pvalue $=$ 0,647), ada hubungan antara pengetahuan dengan perilaku penggunan safety belt (Pvalue $=0,000$ ), tidak ada hubungan antara sikap dengan perilaku penggunan safety belt (Pvalue $=0,621$ ) dan ada hubungan antara masa kerja dengan perilaku penggunan safety belt (Pvalue $=0,000)$.
\end{abstract}

Kata Kunci : Karakteristik pengemudi, perilaku penggunaan safety belt.

\begin{abstract}
In the development of automobile technology is very important for human life cars are equipped with safety devices that safety belt. Traffic accidents are one of the biggest causes of death in Indonesia, the Jakarta Police crack down on about 235 riders who do not use the safety belt and in Bandung violations regarding the use of safety belt \pm 400 violations. Accident data from the Directorate General of Land Transportation of 2009 total accident victims in 2011 reached 176763 people, with details of 31185 dead, 36767 serious injuries and 108 811 suffered minor injuries. According to studies conducted by the Institute of Analysis CEESAR, said the number of truck drivers killed and injured in traffic accidents can be reduced by $40 \%$ if they are all using a safety belt. Law No. 14 of 1992 on the obligation to use safety belt, this offense is liable to imprisonment for one month or a fine Rp1000.000. The purpose of this study was to determine the relationship with the behavioral characteristics of the driver's safety belt use in PT Cipta Hasil Sugiarto Cirebon 2015. This study uses a questionnaire research instruments. The study design was cross-sectional design, with the entire population of the driver in the PT Cipta Hasil Sugiarto Cirebon many as 70 respondents and sampling using the method of the total population. Data were statistically analyzed using chi square test at 5\% significance level (0.05).

The results showed no relationship between age and the behavior of the use of safety belt (pvalue $=0.000$ ), there was no correlation between level of education and the behavior of the use of safety belt (pvalue $=0.647$ ), there is a relationship between knowledge and behavior of the use of safety belt (pvalue $=0.000$ ), there is no relationship between attitude and behavior of the use of safety belt (pvalue $=0.621$ ) and there is a relationship between the period of employment with the behavior of the use of safety belt (pvalue $=0.000$ ).
\end{abstract}

Keywords: Driver characteristics, safety belt usage behavior.

* Alumni PSKM STIKes Cirebon Lulus Tahun 2015

** Staf Pengajar Program Studi S1 Kesehatan Masyarakat STIKes Cirebon 


\section{PENDAHULUAN}

Dalam perkembangannya teknologi sangatlah berperan untuk membuat mobil yang baik, mobil yang baik adalah mobil yang dapat membantu pengendara menghindari terjadinya kecelakaan dan juga dapat melindungi pengendara dan penumpang sewaktu kecelakaan terjadi. Untuk dapat membantu pengendara menghindari terjadinya kecelakaan, mobil dilengkapi dengan perangkat keamanan yaitu dengan adanya sabuk pengaman. ${ }^{1}$

Kecelakaan lalu lintas merupakan salah satu penyebab kematian terbesar di Indonesia. Jumlah korban yang cukup besar akan memberikan dampak ekonomi (kerugian material) dan sosial yang tidak sedikit, berbagai usaha preventif hingga perbaikan lalu lintas dengan melibatkan berbagai pihak yang terkait hasilnya belum sesuai yang diharapkan. ${ }^{2}$

Dalam kehidupan sehari-hari masyarakat Indonesia yang mengendarai mobil tanpa menggunakan safety belt dengan benar, walaupun mereka menyadari pentingnya penggunaan safety belt bagi keselamatan diri saat mengendarai mobil, serta risiko denda yang akan mereka terima dari pemerintah bila mereka tidak menggunakan safety belt saat mengendarai mobil. Banyaknya pelanggaran mengenai penggunaan safety belt, Polda Metro Jaya telah menindak sekitar 235 pengendara yang tidak menggunakan sabuk pengaman (safety belt) di wilayah Polda Metro Jaya, termasuk Bogor, Depok, Bekasi. Di Bandung sendiri pelanggaran mengenai penggunaan sabuk pengaman kurang lebih 400 pelanggaran. ${ }^{1}$

Data kecelakaan yang ada dari Jasa Marga dari tahun ke tahun bahwa penyebab kecelakaan yang terbesar disebabkan oleh faktor manusia (pengemudi). Penyebab kecelakaan yang dilakukan akibat kendaraan. ${ }^{2}$

Perangkat keamanan mobil yaitu kerangka mobil yang diperkuat, sabuk pengaman pada setiap kursi, kantong udara (airbag), pelindung kepala (head restrain), dan besi pelindung di tiap pintu (side beam). Dari berbagai kecelakaan yang terjadi di berbagai negara, tampak jelas bahwa di samping kerangka mobil yang diperkuat, sabuk pengamanlah yang merupakan perangkat keamanan yang paling penting dalam melindungi pengendara dan penumpang sewaktu kecelakaan terjadi. ${ }^{1}$

Dalam suatu kejadian kecelakaan, kendaraan harus memiliki perangkat yang memadai seperti sabuk keselamatan (safety belt) dan bantal pengaman (airbag); dan layanan medis darurat harus tersedia bagi korban kecelakaan. Demikian pula lingkungan dan kendaraan harus memiliki atribut tertentu sebagai pencegahan untuk meminimalkan angka kematian. ${ }^{3}$

Menurut studi yang dilakukan oleh Institut Analisis CEESAR, mengatakan jumlah pengemudi truk yang meninggal dan terluka dalam kecelakaan lalu lintas dapat dikurangi $40 \%$ jika mereka semua menggunakan sabuk pengaman atau safety belt. Penelitian Akhmad Wahidin tentang hubungan karakteristik pengemudi dengan perilaku penggunaan sabuk keselamatan (safety belt) pada mahasiswa Universitas Semarang mengatakan bahwa tigkat pendidikan, umur, pengetahuan dan sikap berhubungan dengan perilaku penggunaan safety belt. ${ }^{3}$ Penelitian Kurniawan tentang hubungan perilaku penggunaan sabuk keselamatan (safety belt) pada pengemudi bus malam mengatakan ada hubungan antara sikap dan masa kerja dengan perilaku penggunaan safety beltmasa kerja dapat mempengaruhi perilaku seseorang. ${ }^{4}$

PT. Cipta Hasil Sugiarto dikenal sebagai salah satu perusahaan jasa transportasi dan penyewaan alat-alat berat terkemuka di Indonesia terutama dalam industri minyak dan gas. PT. Cipta Hasil Sugiarto Cirebon memiliki 70 orang pengemudi. Berdasarkan data yang diperoleh di PT. Cipta Hasil Sugiarto data kecelakaan kerja tahun 2014 Januari awal sampai dengan Desember akhir 2014 didapatkan jumlah Medical treatment (yang membutuhkan perawatan medis) 3 kasus, First aid (kotak P3K) 3 kasus, Near miss (hampir celaka) 6 kasus, MVC/motor vehicle crash (kecelakaan kendaraan) 5 kasus, Property demage (kerusakan) 39 kasus. Tujuan penelitian ini adalah untuk mengetahui hubungan karakteristik pengemudi dengan perilaku penggunaan safety belt di PT Cipta Hasil Sugiarto Cirebon tahun 2015. 


\section{METODE}

Penelitian ini merupakan jenis penelitian kuantitatif dengan desain cross sectional. Variabel penelitian adalah umur, tingkat pendidikan, pengetahuan, sikap dan masa kerja sebagai variabel bebas (Variabel Independen) dan perilaku pengemudi dalam menggunakan safety belt sebagai variabel terikat (Variabel Dependen). Populasi dalam penelitian ini adalah seluruh pengemudi di PT. Cipta Hasil Sugiarto Cirebon tahun 2015 dengan jumlah 70 orang pengemudi. Teknik pengambilan sampel adalah total sampling yaitu sebanyak 70 orang pengemudi. Instrumen pada penelitian ini menggunakan kuesioner untuk mengetahui umur, tingkat pendidikan, pengetahuan, sikap, masa kerja dan perilaku pengemudi dalam menggunaan safety belt. Analisis data menggunakan analisa univariat dan bivariat. Analisis bivariat menggunakan uji statistik chi Square.

\section{HASIL PENELITIAN}

\section{Umur, Pendidikan, Pengetahuan, Sikap, Masa Kerja}

Tabel 1. Distribusi Frekuensi Menurut Umur, Pendidikan, Pengetahuan, Sikap, Masa Kerja

\begin{tabular}{|c|c|c|}
\hline Kriteria & Frekuensi & Persen $(\%)$ \\
\hline \multicolumn{3}{|l|}{ Umur } \\
\hline$<25$ Tahun & 19 & 27,1 \\
\hline$\geq 25$ Tahun & 51 & 72,9 \\
\hline \multicolumn{3}{|l|}{ Pendidikan } \\
\hline SD-SMP (dasar) & 27 & 38,6 \\
\hline SMA-PT (tiggi) & 43 & 61,4 \\
\hline \multicolumn{3}{|l|}{ Pengetahuan } \\
\hline Kurang Baik & 23 & 32,9 \\
\hline Baik & 47 & 67,1 \\
\hline \multicolumn{3}{|l|}{ Sikap } \\
\hline Tidak setuju & 31 & 44,3 \\
\hline Setuju & 39 & 55,7 \\
\hline \multicolumn{3}{|l|}{ Masa Kerja } \\
\hline$<5$ tahun & 19 & 27,1 \\
\hline$\geq 5$ tahun & 51 & 72,9 \\
\hline
\end{tabular}

Berdasarkan tabel 1 distribusi frekuensi menurut umur responden menunjukan bahwa sebagian besar responden memiliki umur $\geq 25$ sebanyak 51 orang $(72,9 \%)$, responden memiliki tingkat pendidikan SMA-PT (tinggi) sebanyak 43 orang $(61,4 \%)$, pengetahuan responden baik sebanyak 47 orang $(67,1 \%)$, sikap responden sebagian besar yang setuju sebanyak 39 orang $(55,7 \%)$, masa kerja responden sebagian besar responden yang $\geq 5$ tahun sebanyak 51 orang $(72,9 \%)$.

\section{Perilaku}

Hasil penelitian menunjukkan bahwa distribusi frekuensi menurut perilaku responden menunjukkan bahwa sebagian responden menggunakan safety belt sebanyak 40 orang $(57,2 \%)$ sedangkan sisanya yang tidak menggunakan safety belt sebanyak 30 orang $(42,9 \%)$. 


\section{Hubungan antara umur dengan perilaku penggunaan safety belt}

Tabel 2. Hubungan antara Umur dengan Perilaku Penggunaan Safety Belt

\begin{tabular}{|c|c|c|c|c|c|c|c|}
\hline \multirow[t]{3}{*}{ Umur } & \multicolumn{4}{|c|}{ Perilaku penggunaan safety belt } & \multicolumn{2}{|c|}{ Total } & \multirow[t]{2}{*}{ Pvalue } \\
\hline & \multicolumn{2}{|c|}{ Tdk Menggunakan } & \multicolumn{2}{|c|}{ Menggunakan } & & & \\
\hline & $\mathrm{N}$ & $\%$ & $\mathrm{~N}$ & $\%$ & $\mathrm{~N}$ & $\%$ & \\
\hline$<25$ Tahun & 19 & 27,1 & 0 & 0 & 19 & 100 & 0,000 \\
\hline$\geq 25$ Tahun & 0 & 0 & 51 & 72,9 & 51 & 100 & \\
\hline Total & 30 & 27,1 & 40 & 72,9 & 70 & 100 & \\
\hline
\end{tabular}

Berdasarkan tabel 2 diperoleh dari $51(72,9 \%)$ responden yang berumur $\geq 25$ tahun menggunakan safety belt dan dari $19(27,1 \%)$ responden yang berumur $<25$ tahun tidak menggunakan. Berdasarkan hasil uji statistik diperoleh nilai $p$-value sebesar 0,000 artinya $<\alpha$ $(0,05)$, berarti ada hubungan antara umur dengan perilaku penggunaan safety belt di PT Cipta Hasil Sugiarto Cirebon tahun 2015.

\section{Hubungan antara pendidikan dengan perilaku penggunaan safety belt}

Tabel 3. Hubungan antara Pendidikan dengan Perilaku Penggunaan Safety Belt

\begin{tabular}{|c|c|c|c|c|c|c|c|}
\hline \multirow[t]{3}{*}{ Pendidikan } & \multicolumn{4}{|c|}{ Perilaku penggunaan safety belt } & \multicolumn{2}{|c|}{ Total } & \multirow[t]{2}{*}{ Pvalue } \\
\hline & \multicolumn{2}{|c|}{ Tdk Menggunakan } & \multicolumn{2}{|c|}{ Menggunakan } & & & \\
\hline & $\mathrm{N}$ & $\%$ & $\mathrm{~N}$ & $\%$ & $\mathrm{~N}$ & $\%$ & \\
\hline $\begin{array}{l}\text { SD-SMP } \\
\text { (dasar) }\end{array}$ & 6 & 22,2 & 21 & 77,8 & 27 & 100 & 0,463 \\
\hline SMA (tinggi) & 13 & 30,2 & 30 & 69,8 & 43 & 100 & \\
\hline Total & 19 & 27 & 40 & 73 & 70 & 100 & \\
\hline
\end{tabular}

Berdasarkan tabel 3 diperoleh bahwa dari 43 responden (100\%) yang tingkat pendidikannya SMA-PT (tinggi) terdapat 30 responden $(69,8 \%)$ menggunakan safety belt sedangkan dari 27 responden $(100 \%)$ yang tingkat pendidikannya SD-SMP (dasar) terdapat 21 responden $(77,8 \%)$ menggunakan safety belt. Berdasarkan hasil uji statistik diperoleh nilai p-value sebesar 0,463 artinya $>\alpha(0,05)$, berarti tidak ada hubungan antara tingkat pendidikan dengan perilaku penggunaan safety belt di PT Cipta Hasil Sugiarto Cirebon tahun 2015.

\section{Hubungan antara pengetahuan dengan perilaku penggunaan safety belt}

Tabel 4. Hubungan antara pengetahuan dengan perilaku penggunaan safety belt

\begin{tabular}{|c|c|c|c|c|c|c|c|}
\hline \multirow[t]{3}{*}{ Pengetahuan } & \multicolumn{4}{|c|}{ Perilaku penggunaan safety belt } & \multicolumn{2}{|c|}{ Total } & \multirow[t]{2}{*}{$\mathrm{P}$ value } \\
\hline & \multicolumn{2}{|c|}{ Tdk Menggunakan } & \multicolumn{2}{|c|}{ Menggunakan } & & & \\
\hline & $\mathrm{N}$ & $\%$ & $\mathrm{~N}$ & $\%$ & $\mathrm{~N}$ & $\%$ & \\
\hline Kurang baik & 19 & 27,1 & 4 & 17,4 & 23 & 100 & 0,000 \\
\hline Baik & 0 & 0 & 47 & 100 & 47 & 100 & \\
\hline Total & 19 & 27,1 & 51 & 72,9 & 70 & 100 & \\
\hline
\end{tabular}

Berdasarkan tabel 4 diperoleh bahwa dari 47 (100\%) responden yang pengetahuannya baik, terdapat $47(100 \%)$ responden menggunakan safety belt sedangkan dari $23(100 \%)$ responden yang pengetahuannya kurang baik terdapat 19 (82,6\%) responden tidak menggunakan safety belt. Berdasarkan hasil uji statistik diperoleh nilai pvalue sebesar 0,000 artinya $<\alpha(0,05)$, berarti ada hubungan antara pengetahuan dengan perilaku penggunaan safety belt di PT Cipta Hasil Sugiarto Cirebon tahun 2015. 


\section{Hubungan antara sikap dengan perilaku penggunaan safety belt di PT Cipta Hasil Sugiarto}

Tabel 5. Hubungan antara sikap dengan perilaku penggunaan safety belt

\begin{tabular}{|c|c|c|c|c|c|c|c|}
\hline \multirow[t]{3}{*}{ Sikap } & \multicolumn{4}{|c|}{ Perilaku penggunaan safety belt } & \multicolumn{2}{|c|}{ Total } & \multirow[t]{2}{*}{ Pvalue } \\
\hline & \multicolumn{2}{|c|}{ Tdk Menggunakan } & \multicolumn{2}{|c|}{ Menggunakan } & & & \\
\hline & $\mathrm{N}$ & $\%$ & $\mathrm{~N}$ & $\%$ & $\mathrm{~N}$ & $\%$ & \\
\hline Tidak setuju & 7 & 22,6 & 24 & 77,4 & 31 & 100 & 0,444 \\
\hline Setuju & 12 & 30,8 & 27 & 69,2 & 39 & 100 & \\
\hline Total & 19 & 42,8 & 40 & 57,3 & 70 & 100 & \\
\hline
\end{tabular}

Berdasarkan tabel 5 diperoleh bahwa dari 39 (100\%) responden yang memiliki sikap setuju, terdapat $27(69,2 \%)$ responden menggunakan safety belt sedangkan dari $31(100 \%)$ responden yang memiliki sikap tidak setuju, terdapat 7 responden $(22,6 \%)$ tidak menggunakan safety belt. Berdasarkan hasil uji statistikdiperoleh nilai p-value sebesar 0,444 artinya $>\alpha(0,05)$, berarti tidak ada hubungan antara sikap dengan perilaku penggunaan safety belt di PT Cipta Hasil Sugiarto Cirebon tahun 2015.

\section{Hubungan antara masa kerja dengan perilaku penggunaan safety belt di PT Cipta Hasil Sugiarto}

Tabel 6. Hubungan masa kerja dengan perilaku penggunaan safety belt

\begin{tabular}{|c|c|c|c|c|c|c|c|}
\hline \multirow[t]{3}{*}{ Masa Kerja } & \multicolumn{4}{|c|}{ Perilaku penggunaan safety belt } & \multicolumn{2}{|c|}{ Total } & \multirow[t]{2}{*}{ Pvalue } \\
\hline & \multicolumn{2}{|c|}{ Tdk Menggunakan } & \multicolumn{2}{|c|}{ Menggunakan } & & & \\
\hline & $\mathrm{N}$ & $\%$ & $\mathrm{~N}$ & $\%$ & $\mathrm{~N}$ & $\%$ & \\
\hline$<5$ tahun & 19 & 100 & 0 & 38,6 & 19 & 100 & 0,000 \\
\hline$\geq 5$ tahun & 0 & 0 & 51 & 18,5 & 51 & 100 & \\
\hline Total & 19 & 27,1 & 51 & 72,9 & 70 & 100 & \\
\hline
\end{tabular}

Berdasarkan tabel 6 diperoleh bahwa dari 51 responden (100\%) yang masa kerjanya $\geq 5$ tahun, terdapat 51 responden $(18,5 \%)$ menggunakan safety belt sedangkan dari 19 (100\%) responden yang masa kerjanya $<5$ tahun, terdapat 19 responden $(100 \%)$ tidak menggunakan safety belt. Berdasarkan hasil uji statistik diperoleh nilai $p$-value sebesar 0,000 artinya $<\alpha$ $(0,05)$, berarti ada hubungan antara masa kerja dengan perilaku penggunaan safety belt di PT Cipta Hasil Sugiarto Cirebon tahun 2015.

\section{PEMBAHASAN}

\section{Hubungan antara umur dengan perilaku penggunaan safety belt}

Berdasarkan hasil uji statistik diperoleh nilai $p$ value sebesar 0,000 artinya $<\alpha(0,05)$. Maka Ho ditolak berarti ada hubungan antara umur dengan perilaku penggunaan safety belt di PT Cipta Hasil Sugiarto Cirebon tahun 2015. Penelitian ini sejalan dengan penelitian sebelumnya oleh Ahmad Wahidin yang menyatakan bahwa terdapat hubungan antara umur dengan perilaku penggunaan safety belt pada mahasiswa Universitas Semarang ${ }^{3}$.

Suma'mur (2009) menyatakan bahwa umumnya perusahaan merekut pekerja yang masih muda karena fisiknya masih kuat, dinamis dan kreatif tetapi usia muda biasanya cepat bosan, penuh emosi, ceroboh, kurang berpengalaman, dan kurang rasa tanggung jawab sehingga menyebabkan timbulnya tindakan yang membahayakan keselamatan dan kesehatan kerja. Sedangkan pekerja berusia tua umumnya kondisi fisiknya kurang tetapi bekerja ulet, tanggung jawabnya besar, lebih dapat dipercaya dan lebih berhati-hati. Sehingga pekerja usia tua cenderung lebih menyadari akan bahaya kecelakaan yang timbul ketika sedang bekerja 
dibandingkan dengan pekerja usia muda. Tapi pada penelitian ini diperoleh data yang paling banyak tidak menggunakan safety belt adalah pekerja yang berumur $\geq 25$ tahun (tua). Jadi semakin dewasa umur seseorang maka akan semakin paham terhadap masalah kesehatan dan yang pada akhirnya juga berpengaruh terhadap perilakunya dalam pentingnya menggunakan safety belt.

\section{Hubungan antara pendidikan dengan perilaku penggunaan safety belt}

Berdasarkan hasil uji statistik diperoleh nilai $p$ value sebesar 0,463 artinya $>\alpha(0,05)$. Maka Ho gagal ditolak berarti tidak ada hubungan antara tingkat pendidikan dengan perilaku penggunaan safety belt di PT Cipta Hasil Sugiarto Cirebon tahun 2015.

Penelitian ini tidak sejalan dengan penelitian sebelumnya oleh Ahmad Wahidin yang menyatakan bahwa terdapat hubungan antara tingkat pendidikan dengan perilaku penggunaan safety belt pada mahasiswa Universitas Semarang ${ }^{3}$.

Pendidikan adalah usaha sadar dan terencana untuk mewujudkan suasana proses pembelajaran agar peserta didik secara aktif mengembangkan potensi dirinya untuk kearah yang lebih baik, menurut UU No. 20 Tahun 2003 mengkategorikan pendidikan menjadi 2 tingkatan yaitu SD-SMP (dasar) dan SMA-PT (tinggi)

Menurut analisa penulis tidak adanya hubungan antara tingkat pendidikan dengan perilaku penggunaan safety belt karena setiap pagi pukul 07:40 semua karyawan yang ada di PT Cipta Hasil Sugiarto Cirebon wajib mengikuti briefing pagi mungkin dengan adanya hal tersebut maka baik tingkat pendidikan dasar maupun tinggi tidak mempengaruhi pada perilaku pengemudi.

\section{Hubungan antara pengetahuan dengan perilaku penggunaan safety belt}

Berdasarkan hasil uji statistik diperoleh nilai $p$ value sebesar 0,000 artinya $<\alpha(0,05)$. Maka Ho ditolak berarti ada hubungan antara pengetahuan dengan perilaku penggunaan safety belt di PT Cipta Hasil Sugiarto Cirebon tahun 2015.

Penelitian ini sejalan dengan penelitian sebelumnya oleh Ahmad Wahidin yang menyatakan bahwa terdapat hubungan antara tingkat pengetahuan dengan perilaku penggunaan safety belt pada mahasiswa universitassemarang. Pengetahuan merupakan hasil dari tahu, dan ini terjadi setelah orang melakukan penginderaan terhadap objek tertentu. Penginderaan terjadi melalui pancaindra manusia, yakni indera pengelihatan, pendengaran, penciuman, rasa dan raba. Sebagaian besar pengetahuan manusia diperoleh melalui mata dan telinga. $^{5}$

Hal ini terjadi karena setiap orang yang memiliki pengetahuan baik maka akan berdampak positif bagi perilaku orang tersebut.

\section{Hubungan antara sikap dengan perilaku penggunaan safety belt}

Berdasarkan hasil uji statistik diperoleh nilai $p$ value sebesar 0,444 artinya $>\alpha(0,05)$. Maka Ho gagal ditolak berarti tidak ada hubungan antara tingkat pendidikan dengan perilaku penggunaan safety belt di PT Cipta Hasil Sugiarto Cirebon tahun 2015. Penelitian ini tidak sejalan dengan penelitian sebelumnya oleh Ahmad Wahidin yang menyatakan bahwa terdapat hubungan antara sikap dengan perilaku penggunaan safety belt pada mahasiswa universitas Semarang. ${ }^{3}$

Menurut Zimbardo dan Ebboson, sikap adalah suatu predisposisi (keadaan mudah terpengaruh) terhadap seseorang, ide, atau objek yang berisi komponen cognitive, affective dan behavior. Dengan mengubah sikap seseorang maka dapat mengubah perilakunya. ${ }^{5}$

Menurut analisa penulis tidak adanya hubungan antara sikap dengan perilaku penggunaan safety belt karena adanya faktor internal. Faktor internal diantaranya keadaan 
psikologis seperti tindakan pengemudi yang tidak menggunakan karena sebagian besar dari mereka berfikir mobil yang mereka kendarai baru akan keluar dari PT CHAS jadi pengemudi banyak yang tidak menggunakan karena belum memulai perjalanan tapi PT CHAS sudah ada aturan tersendiri bahwa mobil akan keluar atau memulai perjalanan akan diperiksa terlebih dahulu oleh Security. Sikap secara realitas menunjukkan adanya kesesuaian respons terhadap stimulus tertentu.

\section{Hubungan antara masa kerja dengan perilaku penggunaan safety belt}

Berdasarkan hasil uji statistik diperoleh nilai p-value sebesar 0,000 artinya $<\alpha(0,05)$. Maka Ho ditolak berarti ada hubungan antara masa kerja dengan perilaku penggunaan safety belt di PT Cipta Hasil Sugiarto Cirebon tahun 2015. Penelitian ini sejalan dengan penelitian sebelumnya oleh Penelitian terdahulu Kurniawan mengenai hubungan karakteristik pengemudi dengan perilaku penggunaan safety belt pada pengemudi bus malam mengatakan ada hubungan antara masa kerja dengan perilaku penggunaan safety belt. ${ }^{4}$

Masa kerja adalah suatu kurun waktu atau lamanya tenaga kerja itu bekerja di suatu tempat. Masa kerja dapat mempengaruhi kinerja baik positif maupun negative. Memberi pengaruh positif pada pekerja bila dengan semakin lamanya masa kerja tenaga kerja semakin berpengalaman dalam melaksanakan tugasnya. Sebaliknya, akan memberi pengaruh negative apabila dengan semakin lamanya masa kerja maka akan timbul kebiasaan pada tenaga kerja. Hal ini biasanya terkait dengan pekerjaan yang bersifat monoton dan berulang-ulang.

Menurut Suma'mur 1995 mengategorikan masa kerja menjadi dua yaitu $<5$ tahun dan $\geq$ 5 tahun. Hal ini terjadi karena semakin lama seseorang bekerja semakin baik juga perilakunya. $^{6}$

\section{SIMPULAN}

1. Ada hubungan yang sigifikan antara umur dengan perilaku penggunaan safety belt di PT Cipta Hasil Sugiarto Cirebon Tahun 2015.

2. Tidak ada hubungan antara tingkat pendidikan dengan perilaku penggunaan safety belt di PT Cipta Hasil Sugiarto Cirebon Tahun 2015.

3. Ada hubungan yang signifikan antara pengetahuan dengan perilaku pengunaan safety belt di PT Cipta Hasil Sugiarto Cirebon Tahun 2015.

4. Tidak ada hubungan antara sikap dengan perilaku penggunaan safety belt di PT Cipta Hasil Sugiarto Cirebon Tahun 2015.

5. Ada hubungan yang signifikan antara masa kerja dengan perilaku penggunaan safety belt di PT Cipta Hasil Sugiarto Cirebon Tahun 2015.

\section{SARAN}

1. Bagi Perusahaan

Meningkatkan pemahaman tentang pentingnya menngunakan safety belt kepada pengemudi sebagai salah satu upaya untuk mengurangi tingkat cidera apabila terjadi kecelakaan.

2. Bagi Pengemudi

Harus lebih mematuhi SOP dan penggunaan APD (alat pelindung diri) safety belt yang telah ditetapkan perusahaan

3. Bagi Peneliti

Diadakan penelitian lebih lanjut dengan menambah variabel yang diduga berhubungan dengan perilaku pengemudi dalam menggunakan safety belt. 


\section{Bagi Tenaga Kesehatan}

Memberikan penyuluhan guna meningkatkan pengetahuan mengenai perilaku penggunaan safety belt yang jika diterapkan dapat mengurangi cidera parah pada pegemudi saat terjadinya kecelakaan.

5. Bagi Peneliti Lain

Selanjutnya diharapkan dapat mengukur variabel perilaku menggunakan metode observasi sehingga mencegah kemungkinan terjadinya bias.

\section{DAFTAR PUSTAKA}

1. K. Salihat. Perilaku Penggunaan Sabuk Keselamatan Pada Mahasiswa; [diakses tanggal 18 Juni 2015]. Diunduh dari http://repository.maranatha.edu

2. Muhammad Asdar. Perilaku Safety Riding Pada Siswa SMA di Kabupaten Pangkep; [diakses tanggal 18 Juni 2015]. Diunduh dari: http://repository.unhas.ac.id

3. Ahmad Wahidin. Hubungan Karakteristik Perilaku Penggunaan Sabuk Keselamatan (safety belt); [diakses tanggal 18 Juni 2015]. Diunduh dari: http://core.ac.uk/download/pdf/11716218.pdf

4. Ahmad Dharief Dahlawy. Faktor-faktor Yang Mempengaruhi Perilaku Keselamatan dan Kesehatan Kerja; [diakses tanggal 18 Juni 2015]. Diunduh dari: http://repository.uinjkt.ac.id

5. Priankarara. Definisi Sikap dan pegetahuan. [diakses tanggal 26 Juni 2015]. Diunduh dari http://priankarara.blogspot.com

6. Masa Kerja. Definisi masa kerja. [diakses tanggal 26 Juni 2015]. Diunduh dari http://penelitihukum.org 